\title{
Kepuasan Dan Kenyamanan Nasabah Terhadap Pelayanan Yang Diberikan Oleh Pt Taspen (Persero) Jambi
}

\author{
${ }^{1}$ Ayudiah Saputri Amelia Handayani, ${ }^{2}$ Kafsul Anwar US \\ 1-2 Jurusan Ekonomi Syariah, Fakultas Ekonomi dan Bisnis Islam, Universitas Negeri Sulthan Thaha \\ Saifuddin Jambi
}

\begin{abstract}
Article history
Received: 03-03-2021

Revised: 11-04-2021

Accepted: 27-05-2021

*Corresponding Author: Ayudiah Saputri Amelia Handayani,

Kafsul Anwar US, Jurusan Ekonomi Syariah, Fakultas Ekonomi dan bisnis Islam,

Universitas Negeri Sulthan Thaha Saifuddin Jambi Email: amaliahandayaniayudiahs $\underline{\text { aputri@gmail.co }} \underline{\mathrm{m}}$
\end{abstract}

\begin{abstract}
Abstrak: Penelitian ini dilatarbelakangi oleh kinerja PT TASPEN (PERSERO) Jambi. PT TASPEN (PERSERO) Jambi sangat memprioritaskan pelayanannya yang baik. Di tengah-tengah proses kinerja pegawai PT TASPEN (PERSERO) Jambi dalam melakukan pelayanan yang baik terdapat banyak hambatan dan kendala, namun PT TASPEN (PERSERO) Jambi terus dapat mempertahankan kualitas pelayanannya. Pendekatan penelitian ini bersifat deskritif kualitatif, pendekatan ini dipilih karena memiliki kesesuaian dengan sifat penelitian yang berupaya mengamati aktivitas PT TASPEN (PERSERO) Jambi dalam mempertahankan kualitas pelayanan yang baik di kantor PT TASPEN (PERSERO) Jambi. Penelitian ini menggunakan tehnik pengumpulan data observasi, wawancara, dan dokumentasi, dengan menerapkan tehnik analisis data yaitu reduksi data, display data, dan verifikasi data.Terdapat beberapa cara untuk mempertahankan pelayanan yang baik yaitu mempertahankan standar pelayanan sesuai dengan Standar Operasional Perusahaan (SOP) PT TASPEN PERSERO Jambi, kemudian dengan menjalin kerja sama dengan SKPD/Pemerintahan daerah Provinsi Jambi serta kota dan kabupaten. Kemudian cara terakhir dengan menyediakan fasilitas-fasilitas penunjang kualitas pelayanan PT TASPEN (PERSERO) Jambi. Setelah keseluruhan langkah-langkah tersebut dilakukan, maka PT TASPEN (PERSERO) Jambi diketahui dapat mempertahankan kualitas pelayanannya yang prima, dan membuat konsumen ataupun nasabah dari PT TASPEN (PERSERO) Jambi merasa nyaman, aman, dan merasa terlayani dengan baik oleh pegawai PT TASPEN (PERSERO) Jambi.

Kata Kunci : Kepuasan,Kenyamanan, Kualitas Pelayanan. Dan Verifikasi Data
\end{abstract}

\section{PENDAHULUAN}

Organisasi merupakan sekelompok orang (dua atau lebih) yang secara formal dipersatukan dalam suatu kerjasama untuk mencapai tujuan yang telah ditetapkan.Sedangkan menurut Stoner organisasi adalah suatu pola hubungan- hubungan yang melalui mana orang-orang di bawah pengarahan manajer mengejar tujuan bersama, dan menurut James D. Mooney organisasi adalah bentuk setiap perserikatan manusia untuk mencapai tujuan bersama. (Rynaldidwitama, 2017) Dalam suatu lembaga organisasi dibutuhkan praktisi- praktisi yang handal dibidangnya seperti humas (hubungan masyarakat).Agar segala tujuan dari lembaga organisasi dapat tercapai dengan maksimal.Seperti dalam segi pelayanan yang sangat, dan harus terpenuhi dalam segi kinerjanya.Hal ini bertujuan agar masyarakat yang dilayani dapat merasa puas, terlayani, dan efeknya suatu lembaga organisasi mendapat citra positif dan reputasi yang baik dimata masyarakat.

Oleh karena itu untuk membangun reputasi yang baik, suatu lembaga porganisasi harus mampu memberikan pelayanan yang terbaik pula. Pelayanan merupakan faktor penting dalam merebut hati masyarakat. Suatu lembaga organisasi harus mampu menjaga 
dan mengelola pelayanan prima.Suatu lembaga organisasi semestinya memposisikan moral di atas segalanya.Perilaku baik merupakan salah satu ajaran Islam dan harus dimiliki oleh setiap praktisi atau pegawai dalam suatu lembaga organisasi.(Herman, 2017) Seperti PT TASPEN (PERSERO) Jambi, lembaga organisasi ini merupakan organisasi yang bergerak dibidang jasa, dan melayani masyarakat merupakan faktor utama dan terpenting di masyarakat. PT TASPEN (PERSERO) Jambi ialah lembaga organisasi negeri di bawah naungan Badan Usaha Milik Negera (BUMN) yang terbentuk untuk menyelenggarakan pembayaran pensiun Pegawai Negeri Sipil dan tunjangan hari tua pensiunan. Jadi, pegawai atau praktisi yang berkerja di PT TASPEN (PERSERO), harus memiliki pengetahuan yang tepat tentang pelayanan.

Terbukti pegawai atau praktisi yang berkerja di PT TASPEN (PERSERO) Jambi sudah memiliki itu semua dengan pada tahun 2010 Kantor TASPEN (PERSERO) Cabang Jambi mendapatkan Penghargaan "Piala Citra Pelayanan Prima" dari Presiden Republik Indonesia. Hal ini menunjukkan bahwa PT TASPEN (PERSERO) Jambi memiliki kualitas pelayanan yang baik, dan prima (berkelanjutan). Pelayanan prima mencerminkan pendekatan seluruhnya dari seorang karyawan kepada masyarakat yang dilayani. Bentuk pelayanan prima yang baik adalah pelayanan yang dilakukan dengan ramah, cepat, tepat, dan nyaman sehingga memenuhi kepuasan atau harapan masyarakat.

Dalam melaksanakan pelayanan yang baik ke masyarakat dan menjalankan tugas pokok, dan fungsinya. PT TASPEN (PERSERO) Jambi pasti memiliki cara ataupun kiatkiat untuk mempertahankan dan menjaga kualitas perlayanannya dengan baik, dan pastinya dengan manajement yang baik pula. Perlu kita ketahui sebelumnya bahwa manajemen adalah seni dalam mengatur system baik orang dan peranggkat lain agar dapat berjalan dan bekerja sesuai dengan ketentuan dan tujuan entitas yang terdiri dari berbagai aktivitas sebagaimana di sebutkan oleh George Terry.

Dari uraian di atas penulis tertarik untuk melakukan observasi dan penelitian terhadap kinerja PT TASPEN (PERSERO) Jambi, untuk mengetahui strategi, perencanaan, dan langkah yang diambil, sehingga dapat mempertahankan kualitas pelayanan serta kenyamanan, kepuasan kepada masyarakat provinsi Jambi. Dengan semua penjelasan yang penulis paparkan ke dalam sebuah Jurnal penelitian dengan judul

\section{"KEPUASAN DAN KENYAMANAN NASABAH TERHADAP PELAYANAN YANG DIBERIKAN OLEH PT TASPEN (PERSERO) JAMBI"}

\section{METODE PENELITIAN}

\section{Pendekatan Penelitian}

Penelitian ini mengunakan pendekatan kualitatif-deskriptif. Deskriptif untuk menjelaskan apa yang terjadi secara lengkap. Bergantung pada pengamatan manusia.( Bogdan \& Biklen, 1992) Pendekatan kualitatif yang bersifat deskriptif untuk melihat bagaimana bagaimana manajemen humas mempertahankan pelayanan di kantor PT TASPEN (PERSERO) Provinsi Jambi. Dalam prosesnya penulis akan mengarahkan penelitian kualitatif yang bersifat deskriptif eksplanatoris ini untuk menjelaskan apa yang terjadi secara lengkap, sedangkan eksplanatoris untuk menjawab mengapa dan bagaimana suatu peristiwa terjadi.(Kartono, 1990)

\section{Sumber dan Jenis Data}




\section{a. Sumber Data}

Sumber data yang dimaksud dalam penelitian ini adalah, sebagai berikut:

Pimpinan PT TASPEN (PERSERO) Provinsi Jambi.

Staf bagian Informasi dan Pelayanan di kantor PT TASPEN (PERSERO) Provinsi Jambi.

\section{b. Jenis data}

Sebagai alat untuk memperlancar dan mempermudah penulis dalam penelitian ini, penulis menggunakan dua golongan data yaitu:

\section{Data Primer}

Data primer adalah data yang diperoleh langsung dari hasil wawancara melalui narasumber atau informan yang dianggap berpotensi dalam memberikan informasi yang relevan dan sebenarnya dilapangan.(Meleong, 2010)

\section{Data Sekunder}

Data sekunder adalah data yang digunakan oleh peneliti, misalnya dari dokumendokumen, catatan-catatan, laporan-laporan, ataupun arsip-arsip resmi, serta literatur lainya yang relevan dalam melengkapu data primer penelitian.Jadi sumber data ini berasal dari pihak pertama, kedua, ketiga, dan seterusnya.Adapun data sekunder yang dibutuhkan dalam penelitian ini adalah sebagai berikut:

Sejarah PT TASPEN (PERSERO) Provinsi Jambi.

Visi dan misi PT TASPEN (PERSERO) Provinsi Jambi.

Struktur organisasi PT TASPEN (PERSERO) Provinsi Jambi.

Program kerja PT TASPEN (PERSERO) Provinsi Jambi.

Dokumen-dokumen yang berkaitan dengan penelitian.

\section{HASIL DAN PEMBAHASAN}

Manajemen berasal dari kata manage (bahasa latinnya manus) yang berarti memimpin, menangani, mengatur atau membimbing. George R. Terry (1972) mendefinisikan manajemen sebagaisebuah proses yang khas dan terdiri dari tindakantindakan seperti perencanaan, pengorganisasian,pengaktifan dan pengawasan yang dilakukan untuk menentukan serta mencapai sasaran-sasaran yang telah ditetapkan melalui pemanfaatan sumber daya manusia dan sumber- sumber lainnya.(Ruslan, 2012)

Ricky W. Griffin mendifinisikan manajemen sebagai sebuah proses perencanaan, pengorganisasian, pengkordinasian, dan pengontrolan sumber daya untuk mencapai sasaran secara efektif dan efesien.

Dari pengertian di atas, dapat kita simpulkan bahwa manajemen adalah seni dalam mengatur system baik orang dan perangkat lain agar dapat berjalan dan bekerja sesuai dengan ketentuan dan tujuan entitas yang terdiri dari berbagai aktivitas sebagaimana di sebutkan oleh George Terry.

Fungsi manajemen itu sendiri mengandung arti bahwa dari berbagai elemen dasar yang ada dan sedang didalam proses manajemen itu sendiri yang menjadi sebuah patokan bagi manajer untuk melaksanakan tugasnya. Menurut buku karya Louis A Alen yang berjudul The Professional Management, manajemen mempunyai beberpa fungsi diantaranya:

\section{Memimpin (Leading)}

Tugas utama dari seorang manajer adalah memimpin suatu organisasi untuk mencapai tujuan yang telah ditentukan organisasi tersebut. Fungsi manajemen sebagai pemimpin diantaranya meliputi : 


\section{a) Pengambilan keputusan (decision maker) \\ b) Komunikasi (communication) \\ c) Memotivasi (motivating)}

\section{Perencanaan (Planning)}

Fungsi manajemen yang berikutnya adalah merencanakan atau perencanaaan (planning) Fungsi perencanaan adalah suatu kegiatan yang dilakukan dimana kegiatan tersebut menjadi tujuan dari perusahaan dengan suatu rencana ataupun sebagai acuan agar bisa meraih tujuan yang telah ditentukan perusahaaan sebelumnya. Perencanaan merupakan suatu cara terbaik untuk mewujudkan dan meyakinkan bahwa tujuan perusahaan yang telah ditentukan dapat tercapai, dikarenakan tanpa adanya perencanaan maka apapun fungsi manajemen tidak dapat berjalan dan tujuannya tidak dapat tercapai. Tugas perencanaan sbb :
a) Membuat estimasi untuk waktu atau periode tertentu.
b) Membuat sasaran serta target perusahaan.
c) Merencanakan urutan kegiatan yang diperlukan untuk pencapaian target tertentu.
d) Mengatur kebutuhan waktu didalam pelaksanaan suatu kegiatan.
e) Menyusun rencana anggaran biaya (RAB).
f) Menyusun SOP atau Standard Operating Procedure tentang pekerjaan yang telah disepakati.
g) Menganalisa dan menetapkan berbagai kebijakan dalam pelaksanaan pekerjaan.

\section{Pengorganisasian (Organizing)}

Pengorganisasian atau Organizing adalah menelaah dan memetakan berbagai kegiatan yang sifatnya lebih besar menjadi beberapa kegiatan yang lebih kecil dengan cara membagi tiap tugas supaya diperoleh kegiatan yang lebih sederhana sehingga tujuan perusahaaan dapat tercapai dengan lebih cermat. Kegiatan pengorganisasian ini sendiri diantaranya menghubungkan serta mengatur pekerjaan sehingga mampu dilaksanakan secara lebih efisien dan lebih efektif antara lain :

a) Menentukan desain struktur organisasi.

b) Menentukan job description atau pembagian pekerjaan dari tiap-tiap jabatan guna meraih sasaran organisasi.

c) Memastikan pendelegasian wewenang serta tanggung jawab, memastikan pertangungjawaban dari hasil pekerjaan yang telah dicapai.

d) Memastikan hubungan yang dapat membedakan antara atasan dan staff.

e) Mendeskripsikan berbagai kegiatan ataupun pekerjaan yang dianggap lebih efektif dan efisien sehubungan dengan pengoptimalan sumber daya manusia untuk meraih tujuan perusahaan.

f) Menentukan desain struktur organisasi.

g) Menentukan job description atau pembagian pekerjaan dari tiap-tiap jabatan guna meraih sasaran organisasi.

h) Memastikan pendelegasian wewenang serta tanggung jawab, memastikan pertangungjawaban dari hasil pekerjaan yang telah dicapai. 
i) Memastikan hubungan yang dapat membedakan antara atasan dan staff.

j) Mendeskripsikan berbagai kegiatan ataupun pekerjaan yang dianggap lebih efektif dan efisien sehubungan dengan pengoptimalan sumber daya manusia untuk meraih tujuan perusahaan.

\section{Pengarahan (Directing)}

Pengarahan atau directing adalah tindakan yang berupaya supaya semua anggota kelompok dapat berusaha untuk meraih tujuan yang sesuai dengan rencana manajerial serta usaha. Proses implementasi program supaya bisa untuk dilakukan oleh semua pihak dalam organisasi tersebut dan juga proses memotivasi supaya seluruh pihak dapat melaksanakan tanggung jawabnya dengan mampu menhasilkan produktifitas yang tinggi dan penuh kesadaran. Fungsi pengarahan serta implementasi memiliki tugas sebagai berikut :

a) Menginflementasikan proses pembimbingan, kepemimpinan, serta pemberian motivasi untuk tenaga kerja.

b) Memberikan penjelasan serta tugas yang teratur mengenai pekerjaan.

c) Menjelaskan kebijakan-kebijakan yang sebelumnya sudah ditetapkan.

\section{Pengawasan (Controlling)}

Proses mengawasi atau yang disebut pengawasan dan pengendalian yang dilakukan untuk memastikan bahwa seluruh rangkaian kegiatan yang telah direncanakan, dilaksanakan secara terorganisasi dapat berjalan dengan lancar. Pengawasan itu sendiri, mempunyai beberapa fungsi sebagai berikut :

a) Menilai serta melakukan evaluasi sebuah keberhasilan dalam meraih tujuan perusahaan serta target bisnis yang disesuaikan dengan tolok ukur yang telah ditentukan.

b) Melakukan langkah cepat dalam mengoreksi serta mengklarifikasi dari ketidaksesuain hasil kerja yang mungkin dapat terjadi.

c) Pengambilan keputusan untuk membuat alternative solusi disaat terjadinya masalah yang berkaitan dengan tidak tercapainya tujuan perusahaaan yang telah ditentukan.

Ilmu manajemen itu sendiri dibedakan menjadi 4 jenis yang umunya banyak dipakai di berbagai perusahaan. Jenis jenis manajemen itu sendiri bisa dijabarkan sebagai berikut:

\section{Manajemen Sumber Daya Manusia}

Manajemen Sumber Daya Manusia ini sendiri mempunyai fungsi untuk mendapatkan sumber daya manusia (SDM) terbaik untuk menjalankan perusahaan ataupun bisnis yang sedang dijalankan serta bagaimana mengatur serta memelihara SDM terbaik yang telah terpilih tersebut untuk bekerja bersama - sama dan memastikan SDM tersebut tetap bekerja dengan keyakinan penuh terhadap hasil serta menjaga kualitas hasil pekerjaannya, memastikan hasilnya tetap atau bahkan mungkin bertambah dimasa yang akan datang.

\section{Manajemen Operasional}

Manajemen operasional mempunyai fungsi menghasilkan suatu produk sesuai standar operasi yang telah ditentukan, produk yang dihasilkan dapat memenuhi keinginan konsumen yang beragam dengan tidak meninggalkan pemakaian teknik produksi yang efisien. 
3. Manajemen Pemasaran

Manajemen pemasaran mempunyai fungsi untuk mengupayakan dan mempelajari serta mengidentifikasi apapun yang diutuhkan konsumen. Didalamnya juga sangat perlu untuk menganalisa kekuatan produk pesaing agar pencapaian target dari perusahaaan dapat maksimal.

\section{Manajemen Keuangan}

Manajemen keuangan mempunyai fungsi untuk memastikan jika kegiatan bisnis yang dilakukan benar benar dapat memaksimalkan pencapaian tujuan perusahaan secara ekonomi, dimana profit itu sendiri yang menjadi tolak ukurnya. Fungsi terpenting dari manajemen keuangan ini sendiri adalah memastikan bahwa perencanaan modal perusahaan benar benar bisa diperoleh untuk membiayai bisnis serta mengatur bagaimana modal yang telah didapatkan agar dialokasikan dengan tepat sehingga tujuan perusahaan dapat tergapai secara maksimal.

Pengertian pelayanan menurut J.Supranto adalah sebuah kata yang bagi penyedia jasa merupakan sesuatu yang harus dikerjakan dengan baik.Sedangkan definisi pelayanan menurut Gronroos adalah suatu aktivitas atau serangkaian aktivitas yang bersifat tidak kasat mata yang terjadi sebagai akibat adanya interaksi antara nasabah dengan karyawan atau hal-hal lain yang disediakan oleh perusahaan pemberi pelayanan yang dimaksud untuk memecahkan permasalahan konsumen / nasabah. Pelayanan merupakan faktor yang amat penting khususnya bagi perusahaan yang bergerak dibidang jasa.Dimana hal ini fisik produk biasanya ditunjang dengan berbagai macam inisial produk.Adapun inti produk yang dimaksud biasanya merupakan jasa tertentu.Oleh karena itu pentingnya mengetahui secara teoritis tentang batasan, pengertian dan faktor-faktor yang mempengaruhi dari pada pelayanan itu sendiri. (Winarsih \& Ratmito, 2005) Pelayanan yang diberikan oleh setiap perusahaan tentunya mempunyai tujuan. Umumnya tujuan dengan diadakannya pelayanan adalah agar konsumen merasakan adanya kepuasan dan dampaknya bagi perusahaan akan memperoleh laba maksimum.(Suprapto, 2006)

Dimensi Kualitas Pelayanan (SERVQUAL) oleh Parasuraman (1998) dibagi menjadi lima dimensi SERVQUAL diantaranya adalah

1. Tangibles (bukti fisik) yaitu kemampuan suatu perusahaan dalam menunjukkan eksistensinya kepada pihak eksternal. Penampilan dan kemampuan sarana dan prasarana fisik perusahaan dan keadaan lingkungan sekitarnya adalah bukti nyata dari pelayanan yang diberikan oleh pemberi jasa. Yang meliputi fasilitas fisik (gedung, gudang, dan lain sebagainya), perlengkapan dan peralatan yang dipergunakan (teknologi), serta penampilan pegawainya.

2. Reliability (kehandalan) yaitu kemampuan perusahaan untuk memberikan pelayanan sesuai yang dijanjikan secara akurat dan terpercaya. Kinerja harus sesuai dengan harapan pelanggan yang berarti ketepatan waktu, pelayanan yang sama untuk semua pelanggan tanpa kesalahan, sikap yang simpatik, dan dengan akurasi yang tinggi.

3. Responsiveness (ketanggapan) yaitu kemauan untuk membantu dan memberikan pelayanan yang cepat (responsif) dan tepat kepada pelanggan, dengan penyampaian informasi yang jelas.

4. Assurance (jaminan dan kepastian) yaitu pengetahuan, kesopansantunan, dan kemampuan para pegawai perusahaan untuk menumbuhkan rasa percaya para pelanggan kepada perusahaan. Terdiri dari beberapa komponen antara lain komunikasi, kredibilitas, keamanan, kompetensi, dan sopan santun. 
5. Emphaty (empati) yaitu memberikan perhatian yang tulus dan brsifat individual atau pribadi yang diberikan kepada para pelanggan dengan berupaya memahami keinginan konsumen. Dimana suatu perusahaan diharapkan memiliki pengertian dan pengetahuan tentang pelanggan, memahami kebutuhan pelanggan secara spesifik, serta memiliki waktu untuk pengoperasian yang nyaman bagi pelanggan. (Lupiyodi, 2010)

PT TASPEN (PERSERO) Provinsi Jambi, lembaga organisasi ini merupakan organisasi yang bergerak dibidang jasa, dan melayani masyarakat merupakan faktor utama dan terpenting dimasyarakat. PT TASPEN (PERSERO) Provinsi Jambi ialah lembaga organisasi yang terbentuk untuk menyelenggarakan pembayaran pensiun Pegawai Negeri Sipil. ${ }^{10}$ PT TASPEN (PERSERO) Provinsi Jambi merupakan Cabang tipe $\mathrm{C}$ yang dibawahi oleh PT TASPEN (PERSERO) Kantor Cabang Utama Medan. Wilayah kerja PT TASPEN (PERSERO) Kantor Cabang Provinsi Jambi terdiri dari 1 Pemerintahan Provinsi, 2 Pemerintahan Kota dan 9 Kabupaten.Adapun Wilayah kerja tersebut adalah sebagai berikut :

1. Pemerintahan Provinsi Jambi

2. Pemerintahan Kota Jambi

3. Pemerintahan Kota Sungai Penuh

4. Pemerintahan Kabupaten Muara Jambi

5. Pemerintahan Kabupaten Batanghari

6. Pemerintahan Kabupaten Tanjung Jabung Timur

7. Pemerintahan Kabupaten Tanjung Jabung Barat

8. Pemerintahan Kabupaten Sarolangun

9. Pemerintahan Kabupaten Tebo

10. Pemerintahan Kabupaten Bungo

11. Pemerintahan Kabupaten Merangin

12. Pemerintahan Kabupaten Kerinci

Dengan adanya penugasan dari Pemerintah kepada PT TASPEN (PERSERO) untuk menyelenggarakan pembayaran pensiun Pegawai Negeri Sipil Pusat di wilayah Sumatera berdasarkan SK Menteri Keuangan Nomor 702/KMK.03/1987 tanggal 31 Oktober 1987 dan penugasan pembayaran pension Pegawai Negeri Sipil Daerah Otonom berdasarkan SK Mendagri No. 842.1-1402 Tanggal 14 November 1987, maka dibukalah Kantor Cabang PT TASPEN (PERSERO) Kantor Cabang Provinsi Jambi tepatnya pada bulan Desember 1987 dengan menyewa sebuah gedung berlantai satu yang terletak di Jl. Arief Rachman Hakim No.24 Jambi. Terhitung mulai bulan Januari 1988 secara resmi Kantor Cabang PT TASPEN (PERSERO) Provinsi Jambi dioperasikan.

Perkembangan selanjutnya, terhitung mulai 1 April 1989.Untuk menunjang keberhasilan usaha pelayanan, maka diperlukan sarana dan prasarana yang memadai, antara lain dengan adanya Gedung Kantor yang permanent dan representative. Maka dibangunlah Gedung Kantor PT TASPEN (PERSERO) Cabang Jambi yang beralamat di Jl. Slamet Riyadi di atas tanah seluas $1.700 \mathrm{M}^{2}$ dengan luas bangunan $1.055 \mathrm{M}^{2}$ yang dibangun dengan berciri khas Daerah Jambi.Gedung Kantor PT TASPEN ( PERSERO ) Cabang Jambi diresmikan pada tanggal 05 November 1995 oleh Gubernur Provinsi Jambi H. Abdoerrachman Sayoeti didampingi Direktur Teknik PT TASPEN (PERSERO) H. Umaran Mansyur saat itu dan hingga kini masih berdiri dengan megah. 
Menurut Kotler, kualitas pelayanan merupakan totalitas dari bentuk karakteristik barang dan jasa yang menunjukkan kemampuannya untuk memuaskan kebutuhan pelanggan, baik yang nampak jelas maupun yang tersembunyi. Bagi perusahaan yang bergerak di sektor jasa, pemberian pelayanan yang berkualitas pada pelanggan merupakan hal mutlak yang harus dilakukan apabila perusahaan ingin mencapai keberhasilan.

Begitupun PT TASPEN PERSERO Jambi yang mementingkan kualitas pelayanan dalam pekerjaannya.Manfaat adanya pemberian pelayanan yang baik terhadap nasabah Pelayanan yang baik tentu akan memberikan hal yang baik pula untuk perusahaan. Karena pelayanan ini merupakan wujud tanggung jawab sosial perusahaan, maka ini dapat memberikan keuntungan tersendiri untuk perusahaan seperti:

1. Konsumen akan setia kepada perusahaan

2. Karena konsumen merasa pelayanan perusahaan sangat baik, konsumen bisa jadi akan menjadi pelanggan tetap perusahaan tersebut.

3. Konsumen bisa menjadi media iklan gratis

4. Dengan kepuasan konsumen terhadap pelayanan perusahaan, konsumen bisa saja menyebarkan mengenai hal tersebut kepada rekan- rekan atau tetangganya sehingga perusahaan bisa menjadi lebih dikenal.

5. Kelangsungan bisnis jangka panjang terjamin

6. Dengan semakin banyaknya pelanggan tetap perusahaan, maka perusahaan tidak perlu khawatir tidak akan mendapat pelanggan, karena sudah adanya para pelanggan tetap tersebut.

7. Konsumen tidak akan mempermasalahkan mengenai harga

8. Karena rasa kepercayaan konsumen terhadap perusahaan, maka konsumen tidak akan mempermasalahkan mengenai harga terhadap suatu produk yang ditawarkan perusahaan.

9. Konsumen merasa puas karena kebutuhannya terpenuhi

10. Kebutuhan konsumen bukan hanya dari kualitas produk, melainkan juga dari segi kualitas pelayanan perusahaan. Dengan pelayanan yang baik, maka konsumen akan merasa bahwa semua kebutuhannya telah dipenuhi oleh perusahaan.

11. Nama baik perusahaan meningkat

12. Hal ini dikarenakan semakin banyaknya konsumen yang merasa puas dan menjadi konsumen setia sehingga nama baik perusahaan pun meningkat di mata semua konsumen.

13. Unggul dalam persaingan bisnis

14. Maksudnya unggul disini yaitu perusahaan bisa dikatakan satu langkah didepan perusahaan lainnya dalam bersaing karena konsumen telah mempercayai baik dari segi pelayanan maupun kualitas produk perusahaan tersebut.

15. PT TASPEN PERSERO Jambi itu didasari dengan kebutuhan masyarakat bagi pensiunan dan penerima jasa dari PT TASPEN PERSERO Jambi. Pegawai PT TASPEN PERSERO Jambi melayani pengguna jasa sesuai ketentuan dan peraturan yang ada sesuai dengan Standar Operasional Perusahaan (SOP) KANTOR PT TASPEN PERSERO Jambi itu sendiri.Sehingga timbal balik yang ditunjukkan atau sikap yang ditunjukkan pengguna jasa sangat baik kepada pegawai PT TASPEN PERSERO Jambi. 


\section{KESIMPULAN}

George R. Terry mendefinisikan manajemen sebagaisebuah proses yang khas dan terdiri dari tindakan-tindakan seperti perencanaan, pengorganisasian,pengaktifan dan pengawasan yang dilakukan untuk menentukan serta mencapai sasaran-sasaran yang telah ditetapkan melalui pemanfaatan sumber daya manusia dan sumber- sumber lainnya.Ricky W. Griffin mendifinisikan manajemen sebagai sebuah proses perencanaan, pengorganisasian, pengkordinasian, dan pengontrolan sumber daya untuk mencapai sasaran secara efektif dan efesien. Fungsi manajemen yang berikutnya adalah merencanakan atau perencanaaan Menyusun rencana anggaran biaya Menganalisa dan menetapkan berbagai kebijakan dalam pelaksanaan pekerjaan.

Mendeskripsikan berbagai kegiatan ataupun pekerjaan yang dianggap lebih efektif dan efisien sehubungan dengan pengoptimalan sumber daya manusia untuk meraih tujuan perusahaan.Pengertian pelayanan menurut J.Supranto adalah sebuah kata yang bagi penyedia jasa merupakan sesuatu yang harus dikerjakan dengan baik.Sedangkan definisi pelayanan menurut Gronroos adalah suatu aktivitas atau serangkaian aktivitas yang bersifat tidak kasat mata yang terjadi sebagai akibat adanya interaksi antara nasabah dengan karyawan atau hal-hal lain yang disediakan oleh perusahaan pemberi pelayanan yang dimaksud untuk memecahkan permasalahan konsumen / nasabah. Umumnya tujuan dengan diadakannya pelayanan adalah agar konsumen merasakan adanya kepuasan dan dampaknya bagi perusahaan akan memperoleh laba maksimum.

\section{DAFTAR PUSTAKA}

Herman. 2017. Menjaga Kualitas Pelayanan. http://www.lintasgayo.com/52805/menjagakualitas-pelayanan.html,tanggal 3 april 2017

K. Kartono. 1990. Pengantar Metodologi Riset Sosial. Bandung: Mandar Maju.

Moleong, Lexi J. 2001. Metode Penelitian Kualitatif. Bandung:PT. Remaja Rosdakarya.

Rambat lupiyodi. 2010. Manajemen Pemasaran Jasa. Edisi Pertama. Salemba Empat: Jakarta. 34-35.

Ratminto dan Atik Winarsih. 2005. Manajemen Pelayanan.Pustaka Pelajar: Yogyakarta. 40-43.

RC. Bogdan \& Biklen. 1992. Quantitative Research and Introduction toi Theory and method. London: allyn and bacon. 27-30.

Rosady Ruslan.2012. Manajemen Public Relatioans dan Media Komunikasi: Konsepsi dan Aplikasi. Jakarta: PT RajaGrafindo Persada.

Rynaldidwitama. 2017. Pengertianorganisasidanpengorganisasian diakses melalui alamat http://blogputuyuda01.blogspot.com/2009/11/pengertian-struktur-organisasidan.html,tanggal 3 april 2017

Tsp Jambi, "Profil dan penjelasan tentang Taspen Provinsi Jambi”, diakses melalui alamat https://taspeninfo.wordpress.com/2010/07/31/profil-pt-taspen-perserojambi/.Tanggal 3 April 2017 
Ayudiah Saputri \& Kafsul Anwar 2021

Supranto. 2006. Pengukuran Tingkat Kepuasan Pelanggan. Cetakan Ketiga. Rineka Cipta: Jakarta. 